\title{
Okinawa Narratives: Delineating rhetoric, policy and agency
}

\section{Ra Mason ${ }^{1}$}

School of Politics, Philosophy, Language and Communication Studies, University of East Anglia, UK

\begin{abstract}
By focusing on the divergence between mainstream framings of Okinawa, actual policies directed towards the Ryukyu Islands and the sociopolitical reality on these outlying islands, this article reexamines the often misrepresented role of Okinawan agency. In so doing, it focuses on the various narratives of Okinawa and the key terms that have articulated them in the post-reversion era. It thereby adds explanatory power to extant structuralist and critical literatures, which have tended to suffer from monolithic descriptions of structural power and polemic approaches to American and Japanese governance of the Islands. Specifically, by analyzing a series of illustrative issue areas such as sexual and economic exploitation, environmental protection, and military security, the article uses an adapted form of critical discourse analysis (CDA) to trace how framings and policy have shifted since reversion to Japanese rule. This focuses on primarily on Prime Ministerial statements from the National Diet and other, mostly Japanese language-based, materials relating to Okinawa's governance. These are contrasted with short case studies highlighting the disconnect between rhetoric and reality. Ultimately, the evidence points to a decoupling of mainstream narratives from the on-the-ground reality. The article thereby provides a nuanced understanding and expression of Okinawa's complex interests and agency.
\end{abstract}

${ }^{1}$ CONTACT: Ra Mason $\bowtie$ Ra.Mason@uea.ac.uk 
As the main island of the Ryūkyū Chain, Okinawa is the so-called 'Cornerstone of the Pacific'. ${ }^{2}$ It lies in a pivotal geostrategic position between China and Japan, on the fault-line of current superpower rivalries, with the Ryūkyūs ${ }^{3}$ effectively comprising the island-chain frontier of a United States (US)-Japan security alliance which is seeking to strategically encircle China. ${ }^{4} \mathrm{As}$ a legacy of the Allies' victory in World War II and as a continued function of US strategic interests throughout the post-war era ${ }^{5}$, Okinawa still hosts close to seventy five per cent of all US military bases in Japan. It also houses an increasing number of Japan Self Defense Force (JSDF) facilities. ${ }^{6}$ The base construction, or so-called relocation plan, for Marine Corps Air Station Futenma (MCAS Futenma), off-shore of Okinawa's Main Island is emblematic of this fortification. The replacement base, to be situated directly on top of a pristine coral reef which it will obliterate, has faced majority opposition from the prefecture's residents and political representatives alike. ${ }^{7}$ It thus represents a microcosm for how, despite lofty rhetoric, Okinawan agency - defined broadly here in terms of the diverse interests of those resident on Okinawa is treated indifferently when it comes to governance of these contested islands. ${ }^{8}$

Indeed, there is increasing suspicion that this new facility at Henoko, ostensibly for US forces as a replacement for Futenma, will in fact ultimately be used by the JSDF. ${ }^{9}$ Contextualized

\footnotetext{
${ }^{2}$ Ryukyu Shimpo, 9 September 2012.

${ }^{3}$ Okinawa is by extension the official Japanese name for the country's 47th (last-named) prefecture, which is comprised of several of the widely dispersed Ryukyu Island chain.

${ }^{4}$ Son and Mason. 'Building a maritime 'great wall' to contain China?', 437-442; Pilger, 'The Coming War with China'.

${ }^{5}$ Gabe, Resistant Islands, 62.

${ }^{6}$ Okinawa Times, 26 May 2015.

7 Okinawa Times, 22 February 2017; Rabson, 'Henoko and the U.S. Military', 1-3.

${ }^{8}$ McCormack and Norimatsu, Okinawa no ikari.

${ }^{9}$ Akadome, "Henoko shinkichi' ga hoshii no wa beikoku de wa naku bōeishō $d a^{\prime}$; Ikeo, Okada and Mason, 'Watashi ni yokute anata ni ii yonaguni'.
} 
among other complex socioeconomic issues on the Islands, this protracted base project brings into focus how the policy-setting agenda enacted by Tokyo's central government is decoupled from the narratives of development, burden bearing and deterrence, which have been dominant buzzwords articulating its post-reversion Okinawa policy. ${ }^{10}$ At the same time, however, while the dubious motives for promulgating these narratives have been well-covered in the extant literature, sweeping critiques of the US and Japanese central governments have often obfuscated the nuances and conflicting reality of Okinawan agency in responding to governance issues on the Islands.

Therein, the article that follows sheds new light upon the relationship between the dominant terminology used to depict Okinawa, related policy formation, and the complexity of Okinawan agency in response. As such, it provides an original perspective that builds upon existing discursive literature and avoids overreliance upon both structural (realist) and radical (critical) interpretations of Okinawa's contemporary history. This is achieved through an interpretive critical discourse analysis $(\mathrm{CDA})^{11}$, by spotlighting how policies directed towards Okinawa have been implemented from the highest levels of government via their framing under key terms, such as those cited above. In multifold form, it is argued that these have misrepresented the gap between specific political objectives and focus points, and the unfolding sociopolitical reality on Okinawa. In this sense, the article aims to articulate a range of everyday voices from Okinawa which are otherwise largely unarticulated by government, mass-media and academia.

\footnotetext{
${ }^{10}$ Development here corresponds primarily to the Japanese terms shinkō and kaihatsu, burden to futan and deterrence to yokushiryoku.

${ }^{11}$ Wodak, Critical Discourse Analysis, 186.
} 
Analysis of the extant scholarship on contemporary Okinawa exposes endemic tendencies of contrasting over-emphases upon structural power politics on the one hand ${ }^{12}$ and overidentification of a victimized Okinawan population on the other. ${ }^{13}$ This has resulted in polemic approaches towards both Japan's central government and the US military ${ }^{14}$, which inhibits a balanced interpretation of how leading actors have actually driven narratives articulating Okinawa's identity, whilst directing policies that diverge from them on Okinawa. In contrast, this article engages with a discursive body of evidence that tackles pivotal issues such as sexual and economic exploitation, environmental (mis)management and protection, and (military) security from the perspective of Okinawan agency. This serves to illustrate the disconnection between prominent narratives and the on-the-ground realities that they misrepresent. In conclusion, the primary findings express how Okinawa and the complex agency manifest within it has been repeatedly miscast via monolithic buzzwords disseminated through Japan's state authorities, leading media outlets and academics. Okinawa's diverse interests have thereby been largely marginalized by prefecture-specific policies, but these are themselves also found to be decoupled from the key terms that supposedly represent them. ${ }^{15}$

\section{Framings of Okinawa policy: From development and burden to deterrence}

Methodologically, in order to understand how Okinawa has been framed by Japan's mainstream political discourse, the present study utilizes simplified interpretive critical discourse analysis (CDA) which, as discussed further below, interprets how power is articulated and transferred through the intertextual use of language. ${ }^{16}$ In Okinawa's case, this

\footnotetext{
12 Ozawa, Blueprint for a New Japan; Abe, Atarashii kuni e utsukushii kuni e.

${ }^{13}$ Ota, Essays on Okinawa Problems; Takara, Okinawa seikatsushi; McCormack and Norimatsu.

${ }^{14}$ Ōkubo, Gensō no shima okinawa; Hoshino, 'Okinawa no beigun kichi mondai to ningen no anzenhoshō'.

${ }^{15}$ Mason, 'Japan's change in military outlook marks the end of a 'Peace State".

${ }^{16}$ Wood and Kroger, Doing Discourse Analysis, 21-22.
} 
process is identified with reference to terminology that is used in relation to certain kinds of policy trajectories. The CDA therefore helps to illustrates how, through time, a particular set of key-terms shape a given political issue - often in detachment from actual policymaking. To this effect, the article contrasts (Prime)ministerial-level Diet minutes that directly discuss projects and policies on Okinawa with case studies of policy outcomes that illuminate vestedinterests driving the political economy of sectors such as tourism, concrete and sexual services. This spotlights the evolution and recurring instrumentalization of three pivotal key terms: development ${ }^{17}$, burden and deterrence. ${ }^{18}$

Specifically, usage of these terms is shown to be driven by leading postwar political actors in Tokyo, who have tended to narrow the focus of contentious issues, ahistorically, to the postreversion era. ${ }^{19}$ This ahistorical framing ignores Okinawa's independent history and leans towards identifying Okinawans as essentially victims of American, rather than Japanese, subjugation. Post-reversion, the need for development was emphasized under Japanese governance, as was the burden bearing of US military facilities stationed throughout the prefecture. In the post-9/11 years, however, this has undergone a shift, as the explanation that the regional security environment has become more severe was used to reframe Okinawa as part of an (essential) new security strategy. ${ }^{20}$ This places a heavy emphasis on the deterrence embodied by US military bases on the islands. ${ }^{21}$

\footnotetext{
17 Matsui, Okinawa shinkō no kadai to kongo no shinkōsaku no arikata, 137.

${ }^{18}$ MOD, 'Zaioki beikaiheitai no 'yokushiryoku' ni kansuru shitsumon ni taisuru tōbensho'. ${ }^{19}$ Yōsuke Tsuruho, Special Committee on Okinawa and Northern Problems, 7 December 2016.

${ }^{20}$ Hosoya, 'The Role of Japan's National Security Council', 2.

${ }^{21}$ Newsham, 'US military bases on Okinawa: Still an essential deterrence'.
} 
In this regard, the Japanese government-led narratives of Okinawa's contemporary history largely ignore the brutal antecedents of its current rule by Tokyo's authorities ${ }^{22}$, as well as the geostrategic motives that have underpinned policy throughout the periods identified above. ${ }^{23}$ Such narratives also neglect the majority of Okinawan interests and the changes that the islands have undergone as a function of intensified assimilation and centralized Japanese administration. In that sense, the article also uses CDA to underline the extent to which government policy on Okinawa has been decoupled not only from the concepts manifest in the identified key terms, but also from Okinawan agency itself. It thereby spotlights a plethora of marginalized everyday voices on the ground. In so doing, the process by which Okinawa-policy reflects a strategic but misleading depiction of security logics articulated by Tokyo's leading policy makers is revealed, but the complexity of Okinawan agency - as being far from monolithic in its responses - is also exposed.

\section{Interpreting political terminology}

In the sections that follow, an adapted version of multimodal CDA (MmDA) ${ }^{24}$ - originally initiated by political scientists as a research tool for synthesizing linguistics methods with aspects of psychoanalysis and identity theory ${ }^{25}$ - is applied to a range of selected National Diet records (focusing particularly on Prime Ministerial statements), media reports and other materials. These cover Okinawa's governance and status from the post-Reversion era to the present day. Here, in contrast to proponents of MmDA that typically posit a decentralization of language ${ }^{26}$, this adaptation utilizes the intersubjective and inter-relational interpretation of discourse representative of the MmDA approach in its application to each of the sources listed

\footnotetext{
22 Namihira, Kindai higashiajiashi no naka no ryūkyū heigō, 32-33.

${ }^{23}$ Yoshida, 'US Bases, Japan and the Reality of Okinawa as a Military Colony', 5-7.

24 Paltridge, Discourse Analysis, 69.

${ }^{25}$ See Martinez Lirola, Multimodal Analysis, 248, for an illustrative example.

${ }^{26}$ Norris, What is a Mode?, 155-169.
} 
above, but retains a linguistic focus in terms of how these are understood to facilitate the articulation of politically motivated narratives. Specifically, this effects a critical interpretation of the stated key terms through a diachronic analysis that compares their usage by political actors with related policy outcomes on Okinawa. In particular, this allows for an informed assessment of how discourses identified with development, burden and deterrence became widely disseminated, and how they have contrasted with policymaking and local interests. The qualitative application of CDA is thereby employed to expose, diachronically, how a series of state-level security objectives have dominated Okinawa-policy. These are presented in contradistinction to successive mainstream narratives that are shown to be largely decoupled from the complex facets of Okinawan agency which they impact upon.

This discursive data provides a nuanced understanding of how certain types of framings, prominently represented by these three key terms, have been symptomatic of Okinawa's subjugation and governance, but also excavates how they miscast Okinawan agency as being both monolithic and uniformly victimized. The study therein includes sub-foci on specific issues that have often contributed to misinterpretation and misrepresentation of Okinawan agency across a broad spectrum of the extant literature. ${ }^{27}$ In addition, the combined body of data, as a whole, acts as a case study to illustrate more broadly how political discourse and security policy in Japan have witnessed transformative changes in recent decades. ${ }^{28}$ These amount to political doctrines that have undergone substantive transitions since Okinawa's

\footnotetext{
${ }^{27}$ For further discussion of the misrepresentation of complex Okinawan agency and identities, intersecting state, market and societal spheres, see Matsumura, The Limits of Okinawa; Figal, Beachheads and Inoue, Okinawa and the US Military.

${ }^{28}$ Glosserman and Kang, 'The Myth of Japanese Remilitarization'.
} 
reversion $^{29}$, and are distinguishable from more temporary policy shifts typically associated with, for example, particular leadership figures. ${ }^{30}$

\section{Extant understandings: Agency and policy on Okinawa}

Structuralist (mostly realist-based) approaches tend to understand local-level policy on Okinawa primarily as a function of the competing interests of great powers. This includes Japan and the United States' dual-jurisdiction over the Ryūkyū Islands. ${ }^{31}$ Closer examination of the political processes occurring within Okinawa, however, allows for a shift of focus, from the structure of the US-Japan alliance towards the triangulated, agency-led, relationship comprising the US, Japan and Okinawa. The Prefecture's position within this triangle is endemically weak, ${ }^{32}$ but is also analytically distinct from the key terms that have typically been used to frame it since its reversion.

Okinawa's role in the Vietnam War and American willingness to approve reversion illustrate this to good effect. American bases on Okinawa were extensively utilized to launch combat missions into the conflict, but the spiraling costs of operations meant that US lawmakers were eager to find a way to reduce expenditure in the region. ${ }^{33}$ This included abandoning the costly responsibility of administering and investing in Okinawa's civilian government and placating its dissatisfied residents. ${ }^{34}$ In its place, Japan's growing economic power took up the slack in terms of financial support for Okinawa, including the so-called sympathy budget, or omoiyari yosan, which sees Japanese public funds transferred from Tokyo to Washington in order to

\footnotetext{
${ }^{29}$ Hughes, Japan's Remilitarization, 35-37.

${ }^{30}$ Asahi Shimbun, 21 December 2016; Hatoyama, ed., Higashiajia kyōdōtai to okinawa no mirai; Ota, 'Okinawa kokusai heiwakenkyūjo'.

${ }^{31}$ Kurōzuappu Gendai, "Henoko isetsu' tairitsu no shinsō'.

32 Yamaguchi and Arakawa, The Demise of the Ryukyu Kingdom, viii-ix.

${ }^{33}$ Mitchel, 'Vietnam: Okinawa's forgotten war', 5.

${ }^{34}$ Okinawa Prefectural Peace Memorial Museum, 'Battle of Okinawa'.
} 
subsidize the expenses of US security forces stationed in Japan. ${ }^{35}$ At the same time, on Okinawa, the US government negotiated the almost total continuation of post-reversion base operations. This ensured that existing warfighting capabilities were sustained, but subsidized by Japan - keeping the Status of Forces Agreement (SOFA) much as it was on the islands prior to their legal return. ${ }^{36}$

In accounting for agency within these processes, critical scholarship, including approaches that utilize discourse analyses to focus on the use of key terms for political ends ${ }^{37}$, as well as ethnographic studies, presents an obvious alternative to structural interpretations. Balanced analysis of Okinawan agency in such literature, however, has suffered from a tendency to be undermined by accounts lacking full acknowledgment of the fact that leading political organizations and actors have remained broadly committed to the Ryūkyū Islands' reversion to Japanese rule - rather than promoting independence or emancipation from Japanese oppression. Support for separatist movements, for instance, was effectively subsumed within pro-reversion movements ${ }^{38}$, ultimately leading to a more transnational approach to operationalizing anti-authority agency from within the Prefecture. ${ }^{39}$

Nevertheless, revised attempts by both academics and local interest groups have been made to portray Okinawa as the victim of on-going colonization ${ }^{40}$, including presenting Okinawan interests from proto-nationalist and historical nationalist positions. However, while normative value may be added by such in countering the oppression suffered by Okinawans, critical

\footnotetext{
${ }^{35}$ Okinawa Times, 17 December 2015.

${ }^{36}$ Sato, Amerika seiji to zaioki beigun kichi, 231-232.

${ }^{37}$ Norimatsu, 'Hatoyama Trumps Mubarak', 11-12.

38 Sakurazawa, Okinawa dokuritsu ron no kentō.

39 Dietz, 'Transnationalism and Transition in the Ryūkyūs', 212.

${ }^{40}$ Arazato and Ōshiro, Kindai okinawa no ayumi; Tanji, Myth Protest and Struggle in Okinawa; Takahashi, Okinawa 'fukki' no kōzō.
} 
literature typically needs to show a greater self-awareness of its own biases. This is particularly in terms of misrepresenting the complex and sometimes contradictory political, social and economic interests of many on the Islands, who clearly do not fit the monolithic framing of Okinawa as a unitary victim. The discussion that follows thereby seeks to abridge a growing body of research and scholarship in the area of critical Okinawan studies ${ }^{41}$, which has thus far struggled to gain a wide readership or effectively engage with regional and global counterparts. It also highlights how Okinawa's complex agency is reflective of the negligible sentiments of Ryukyuan nationalist identity now felt within the Prefecture. ${ }^{42}$

Conversely, though, critical approaches do help to illustrate how contemporary Okinawapolicy continues a tradition of dividing and ruling the prefecture, ${ }^{43}$ as described in detail by Lim Chuan-tiong's depiction of the Meiji era disposal of the Ryukyus, or ryukyu shobun, for instance. ${ }^{44}$ Furthermore, Lim's focus on recent history aids in contextualizing current moves to expand and relocate military bases on the Islands. Here, critical scrutiny of dubious security narratives emanating from central authorities in both the US and Japan has been invaluable in providing a more objective representation of the on-the-ground reality. ${ }^{45}$ Within this, the process of "identifying Okinawa as the other", or okinawa no tashaka ${ }^{46}$, is exposed as part of a revisionist appraisal of Japanese national identity, which has been subtly extended to this day. Indeed, such forms of nationalist exclusionism reach to the very core of how Japan's central authorities have utilized political rhetoric to harness power over Okinawan governance

\footnotetext{
${ }^{41}$ Arakawa and Oguma, Oguma kenkyū 1; Takara, Okinawa seikatsushi; Arasaki, Kankō kōsu de nai okinawa; Gabe; Matsushima, Ryukyu dokuritsuron.

${ }^{42}$ Mason, 'Japan's change in military', 20.

${ }^{43}$ Matsumura, The Limits of Okinawa.

${ }^{44}$ Lim, 'Identity Politics in 'Peripheral East Asia", 42-43.

45 The Asahi Shimbun Company, Media, Propaganda and Politics in 20 2 -Century Japan, 183184; Okinawa Times, 29 August 2015.

${ }^{46}$ Takahashi, Okinawa 'fukki' no kōzō, 44.
} 
issues. ${ }^{47}$ Concomitantly, Okinawa's tendency to be "made an exception of to the rule", or reigaika ${ }^{48}$, has continued throughout the post-revision period, and remains central to how the US and Japanese governments implement exceptional laws and policies on Okinawa today. ${ }^{49}$

In sum, then, the extant literature has tended to project polemic framings that risk misrepresenting Okinawa's contemporary political economy and wider society too uniformly. After all, a majority of the Okinawan population now oppose independence and view themselves as Japanese, as well as Okinawan. ${ }^{50}$ Hence, in order to offer an alternative to broadbrush, structuralist, approaches adopted within the mainstream literature, there is a need to deconstruct their monolithic framings - typically expressed using the terms identified within this article - that have underpinned discussion of the prefecture throughout the post-reversion era. In addition, reconstruction of a more accurate depiction of the multitude of voices that reflect sociopolitical reality on Okinawa is also required. The sections below initiate this by contextualizing these key terms in relation to a range of examples from the post-reversion era up to the present day.

\section{Development}

\section{Diet discourse}

Although in terms of absolute frequency, use of the term 'development' in relation to Okinawa became particularly prominent between the years 1982 and 2001, its relative rhetorical primacy within Diet sessions initially emerged in the first decade after reversion (See Figure 1.1). The

\footnotetext{
47 Meisels, Territorial Rights (2 ${ }^{\text {nd }}$ Edition); Moore, National Self-Determination and Secession; Anderson, Imagined Communities.

48 Takahashi, 46-7.

${ }^{49}$ Suda, Yabe and Maedomari, Hondo no ningen wa shiranai ga, 83.

50 Takara, Yokuda and Kuramoto, 'Can we measure 'Okinawan Identity'?', 136; Yoron What Japan Thinks, 'Okinawa identity'; Shimabukuro, “Okinawa aidentiti' to Okinawa jūmin no jiko ketteiken'.
} 
narrative of development can therein be measured quantitatively, as well as qualitatively, as made further evident by its frequent usage in justifying financial policies directed towards the prefecture. Development was also a key term in political competition over which party could assert their credentials to best provide it. For example, immediately after reversion, Finance Committee representative, Kitada Eisaku, alluded to the need, "for the sake of Okinawa's development to be paying particular attention to Okinawa's special circumstances, economic situation and social conditions and such like" ${ }^{, 51}$ when setting up new economic policies directed specifically at the prefecture.

\section{INSERT FIGURE 1.1. Post-Reversion Diet References to Selected Okinawan Issues}

Succeeding Kitada's address, in the five premierships of the first post-reversion decade, successive Liberal Democratic Party (LDP) Prime Ministers echoed his position emphatically. This repeatedly coupled development with reductions to US military facilities, although such rhetoric came to bear little resemblance to the actual trajectory of policy implementation in the Ryūkyūs. Prior to being disgraced, Tanaka Kakuei, for instance, asserted to the Budget Committee that "[w]ith regards pushing ahead with the Okinawa Development Plan...we have determined that there will be a reduction to Okinawa's bases...[as this is] absolutely necessary." ${ }^{52}$ Miki Takeo, likewise, stated that “...in tackling Okinawa's development, I aim to continue to fully engage in actively promoting it forthwith." ${ }^{53}$ Once again, Miki also reinforced Japanese premiers' ongoing separation of Okinawans and mainlanders by preceding his speech with the backhanded statement that the recent Okinawa International Ocean Exposition event of 1975 had been a success partly because "it allowed Okinawans and

\footnotetext{
51 Finance Committee, 25 May 1972.

52 Budget Committee, 10 November 1972.

${ }^{53}$ Main Session, 26 January 1976.
} 
mainland Japanese to form a heartfelt bond" 54 - as if they had previously been somehow unable to do so!

Incoming Prime Minister, Fukuda Takeo, further echoed Tanaka and Miki's sentiments, in places almost verbatim. To this effect, he contended in one statement that "[c]oncerning Okinawa's development, I am inclined to believe that we must continue to make every effort to step up efforts forthwith." ${ }^{55}$ Further, the specific use of development by Japanese leaders, as an overarching key term used to approximate sweeping positive progress on Okinawa, continued through the next two administrations. Prime Minister, Ōhira Masayoshi, for instance, claimed that his government were, “...with regards Okinawa's promotion and development, responding to the on-the-ground situation with the concept of actively extending effective policies" ${ }^{56}$, while his successor, Suzuki Zenkō, defended this emphasis in stating that “...development and promotion have been pushed forward in accordance with the [Okinawa] development plan, and are bearing proportional results". ${ }^{57}$ Here too, it is notable that Suzuki, like those before and after him, continued to focus on a distinction between Okinawans and other Japanese, and link development to ameliorating such a division, "in order to nullify the gap between Okinawa Prefecture and the mainland"58, whilst at the same time, contrarily, reasserting its continuity. In this sense, the generalized use of development as a key term to convey a plethora of positive changes confirms its central role in articulating state-led policy agendas. ${ }^{59}$

\footnotetext{
54 Ibid.

55 Main Session, 15 March 1977.

56 Main Session, 25 January 1980.

57 Cabinet Committee, 25 May 1981.

$58 \mathrm{lbid}$.

${ }^{59}$ Figal, Beachheads, 181-184.
} 
The contradiction, between promoting Okinawa's prosperity to the level of mainland Japan on the one hand and retrenching its distinctive status on the other, has therein been symptomatic of the Islands' framing and governance since their reversion. ${ }^{6061}$ This initially centered on an overemphasis within Diet statements upon the expression and articulation of development, but also involved leading politicians resorting to less ambiguous forms of deception. ${ }^{62}$ In the Diet itself this was illustrated by PM Tanaka, for instance, when he asserted in response to allegations of prohibited nuclear weapons deposits on the Islands that, “...including Okinawa, there are no nuclear weapons in our country." ${ }^{63}$ It was later revealed not only that nuclear weapons had been stored on Okinawa before and after reversion, ${ }^{64}$ but also that this had effectively been agreed upon, including their concealment - to varying degrees of understanding - by former PM, Sato Eisaku, then Defence Minister, Nakasone Yasuhiro, and high-ranking members of the US government, such as Henry Kissinger and Melvin Laird. ${ }^{65}$ Nakasone, in fact, when trying to obtain a more stringent commitment on the removal of nuclear weapons from Okinawa, faced Laird's repost that the word of the US president should be sufficient reassurance. ${ }^{66}$ In this case, that would mean trusting the incumbent Richard Nixon - a man later to be embroiled in the Watergate scandal, and often viewed as an embodiment of duplicity. ${ }^{67}$ The discussion above highlights, then, not only how mainstream discourse on Okinawa's development contains politicized usage of that term, but also how a narrative of development was at-times deliberately falsified.

\footnotetext{
60 Mason, 'Nationalism in Okinawa', 20.

${ }^{61}$ For comparison/continuation, see also Abe Shinzō, Main Diet Session, 14 February 2017.

62 Jimbo and Miyadai, Okinawa no shinjitsu, 188.

63 Upper House Main Session, 1 November 1972.

${ }^{64}$ National Security Archive, 'Nuclear Weapons on Okinawa Declassified December 2015'.

65 Hunt, Melvin Laird and the Foundation of the Post-Vietnam Military, 330-346.

66 Ibid., 46.

${ }^{67}$ Washington Post, 'The Long Shadow of the 'National Nightmare".
} 


\section{Discourse vs. policy and agency}

Contrary to the discourse of development exhibited by Japan's leaders, Tokyo's Okinawapolicy has been determined primarily by a perceived need to couple domestic political stability under the right-of-center LDP administration with US-led national security interests. ${ }^{68}$ This is illustrated by descriptions of various phenomenon embedded within Okinawan society and political economy. Therein, usage of the same key terms becomes less prominent or abandoned altogether. For example, the development narrative has often been deliberately avoided by politicians hailing from all sides - despite being integral to achieving policy objectives - when discussing controversial sectors such as the entertainment industry. Here, in order to maintain relative social order on the Islands, particularly during the final years of the Vietnam War and thereafter, an official policy of extraterritoriality for US personnel under the SOFA worked in tandem with an unofficial local-level policy of promoting the industry (mostly in the form of prostitution) and proliferating narcotics usage ${ }^{69}$ This was initially via the semi- and fullycoerced use of young Okinawan women, later also using foreign women who came to the prefecture as immigrants. ${ }^{70}$ In this sense, given the continuing and urgent need for grass-rootslevel employment opportunities in post-reversion Okinawa, Japanese and American government authorities were either complicit in or indifferent to de facto policies of developing and perpetuating illicit trades and industries. Furthermore, despite lofty rhetoric of increased development initiatives in the name of brining Okinawa in-line, or hondo-nami, with the Japanese mainland, an extensive portion of economic activity in this industry centered around a system absent on the mainland. This involved young women being forced by their families

\footnotetext{
68 Hunt, 332-3.

69 Johnson, 'Three Rapes', 2.

70 OPNLA, 'Current Issues in Post-Reversion Okinawa', 1.
} 
and employers into commercializing their bodies for financial gain, and compounded a socioeconomic structure in which Okinawa's official per capita income remained the lowest in the country and unemployment among the highest. ${ }^{71}$ Okinawa became the prefecture where sex and drugs were traded more freely than any other in Japan, ironically widening the gap between the Ryūkyūs and the mainland Japanese society it was supposedly set to emulate through renewed development. ${ }^{72}$ Yet, Okinawan agency in this regard remained complex and divided, as for many working in these sectors the economic benefits outweighed the social costs of engaging in such industries, despite being the cause of widespread resentment, antiAmerican sentiment and social decay. ${ }^{73}$

In contradistinction to the entertainment industry, the flagship project of the development narrative in this period was the Expo75 international trade fair. This, however, was also not free of controversies. In its inception, it sought to demonstrate both the reality of Okinawa's newly reverted (Japanese) sovereignty and the extensive socioeconomic benefits that Okinawa's commercialization, commodification and resortification could bring. ${ }^{74}$ In fact, as Vivian Blaxell curtly notes, "[t]his production of commodity tourism constituted an important dimension of the mask of Japanese sovereignty in Okinawa. Beach resorts, ocean landscapes, theme parks and packaged representations of Ryukyuan culture concealed the facts of the American war machine and Japanese complicity with it." ${ }^{75}$ In this regard, it should be noted that not only did the Expo75 deflect attention away from the issue of the United States' unabated continuance of military operations directed from the Ryukyus ${ }^{76}$, but also that the

\footnotetext{
${ }^{71}$ Statistics Bureau, 'Labor Force Survey'.

72 JFBA, 'Okinawa fukki nishūnen ni atatte'.

73 Hook and Siddle, Japan and Okinawa, 2-14.

74 Naha City Museum of History, 'Okinawa kokusai kaiyō hakurankai kanren shiryō'.

75 Blaxell, 'Preparing Okinawa for Reversion to Japan', 4.

${ }^{76}$ Sakaiya, 'Okinawa kaiyōhakurankai wa seikō datta ka'.
} 
narrative of Okinawan development was misleading in terms of its suggestion that immediate and widespread economic benefits for Okinawans would be forthcoming. In fact, although Expo75 and its affiliated projects did receive heavy government and quasi-governmental investment, the contracting of giant construction companies, such as Mitsubishi and Fuyō, amongst others, to undertake major infrastructural improvements set an early precedent for how Japan's large mainland companies would dominate and exploit the principal economic development opportunities that exist on Okinawa. The profits of such investment have thereby continued to flow principally into the coffers of giant - typically former zaibatsu conglomerate - firms, and provide only a minimal trickle-down effect for the majority of Okinawa's residents, despite a widespread perception within the prefecture that the Expo was for the benefit of all, with almost universal backing from local residents. ${ }^{77}$

Expo75 and other projects depicted under the umbrella term of development also distracted attention away from protracted US military occupation for the sake of (America's) national defense interests. ${ }^{78}$ Here too, the decoupling of political rhetoric from concrete policies was stark. While Japan's political leaders sustained the portrayal of high levels of government investment and improving socioeconomic conditions on Okinawa, the US military continued to rely heavily on its multiple on-island bases and eventually increased deployments to some 25,000 service members. ${ }^{79}$ With this, the endemic and much-criticized problems of noise pollution, heinous crimes and restricted land usage caused by the heavy US military presence continued. Indeed, the troops were in evident obstruction of Okinawa's wider objective

\footnotetext{
77 Blaxell.

78 Yoshida, 'US Bases, Japan and the Reality of Okinawa as a Military Colony'. ${ }^{79}$ Chanlett-Avery and Rinehart, 'The U.S. Military Presence in Okinawa and the Futenma Base Controversy', 6.
} 
development, apart from the limited short-term economic contribution provided by (mostly onbase) employment and the grey-sector pleasure services already discussed above.

At the same time, this was also an era of governmental investment facilitating the development of large sections of Okinawa's virgin coastline (concretely by way of urbanization and industrialization) via land reclamation and other concrete industry-driven infrastructure projects. Moreover, in terms of agency, most were encouraged and actively endorsed by local authorities and interest groups in the name of development. These witnessed the massive destruction of marine ecosystems surrounding Okinawa's Main Island, including the polluting of rivers and other waterways through reckless use of pesticides and cleaning products, as well as the decimation of fish stocks off the coast of industrialized zones, such as those stretching north and south of the Prefectural capital, Naha ${ }^{80}$ These initiatives were, then, directed by a complex intersection of private commercial, central (Japanese) government, US military and Okinawan agency, but were mostly articulated under the uniform banner of development.

\section{Burden}

\section{Diet discourse}

In transition from the immediate post-reversion years, the 1980s saw the rise of a narrative of burden increasingly projected into mainstream political discourse, which has continued into the $21^{\text {st }}$ century (See Figure 1.1). This emerged in particular under the Nakasone Yasuhiro administration. Nakasone sought to rationalize and foster close US-Japan security relations as part of a broader subtext of the Cold War, famously referring to Japan as the US' "unsinkable aircraft carrier" in the Western Pacific. ${ }^{81}$ Okinawa was, therein, portrayed as central to

\footnotetext{
80 Yamazato, 'Zaijūgaikokujin to no kondankai'.
}

${ }^{81}$ Nakasone, 'Press Statement'. 
maintaining a sufficient deterrence against the Soviet Union and its allies. In this sense, the burden borne by Okinawans referred to a disproportionate but supposedly necessary stationing of US troops on the Ryūkyū Islands, including a heavy contingent of offensive (rather than defensive) Marines under the pretext of national security. ${ }^{82}$

In the Diet, Nakasone lauded that, "We hope to work towards rationalization of th[e] bases as far as possible, but they [Okinawans] are shouldering the burden for an important mission in terms of all the aims of our national defense, as well as confirming the validity of the US-Japan Security Alliance. ${ }^{83}$ Nakasone's successor, Takeshita Noboru, then reinforced this framing of Okinawa and Okinawans by the LDP administration, claiming that, "[use of the bases] is a lynchpin in achieving our objectives under the US-Japan Security Alliance, and...I believe this must be attributed to the understanding and cooperation of all Okinawans." 84

The consistency and broader use of this key term is also striking. In response, Okinawan Diet members, media actors and others from within the prefecture exercised their agency combatively towards this articulation of centralized governance over their islands. This did little, however, to prevent a succession of bureaucrats, Foreign Ministers and Prime Ministers continuing to justify policy trajectories by referring to the burden which Okinawans were portrayed as painfully, but necessarily, shouldering. And, as with the discussion of development, calls by Japan's leaders for "understanding and cooperation" 85 from Okinawans in accepting such a burden were presented as reasonable, responsible and in the public interest ${ }^{86}$

\footnotetext{
82 Sonoda, 'Beigun izon', 1-2.

83 Upper House Main Session, 14 September 1983.

${ }^{84}$ Nakasone Yasuhiro, Main Session, 31 March 1988.

85 Kaifu Toshiki, Main Session, 15 March 1991.

${ }^{86}$ Ibid., Foreign Affairs Committee, 15 June 1990.
} 
- despite being inconsistent with the range of policies being implemented by the central government in Okinawa Prefecture.

Here, the transition of focus from development to burden illustrates a subtle shift, whereby the term, burden, became only relatively more prominent in shaping how Okinawa was framed by leading political and media actors on the Japanese mainland. Indeed, Prime Ministers, Takeshita and Kaifu, for instance, retained development within the same statements in which they had requested "cooperation and understanding" from Okinawans with regards to the heavy burden of US bases that they bear. The post-reversion emphasis on prioritizing Okinawa's development, however, moved towards spotlighting the necessity of the Islands to continue hosting US military forces in large numbers, with the target audience of Okinawa becoming the referent object, in the context of justifying related security measures. ${ }^{87}$ Many statements from leading lawmakers were, therefore, directed explicitly at Okinawans, but were in one sense actually rhetoric spouted tactically on behalf of, or targeting, mainland Japan's electorate. The aim was thereby to identify with mainlanders' collective feelings of guilt towards Okinawa - as the only prefecture which had to suffer both a full US invasion and land-battle during World War II, as well as a disproportionally long occupation thereafter. Concomitantly, an attempt appears to have been made by Japan's ruling elite to "manufacture [mainstream] consent" $" 88$ for its stance on US base hosting among the wider Japanese population.

\section{Discourse vs. policy and agency}

Akin to the smokescreen of development, the narrative of burden bearing also served to distract attention away from controversial aspects of Okinawa-policy, and was effected for audiences

\footnotetext{
${ }^{87}$ Waever, 'Securitization and Desecuritization'.
}

${ }^{88}$ Chomsky and Herman, Manufacturing Consent. 
on both the Japanese mainland and Okinawa itself. In particular, due to burden's association with land usage, noise pollution, and incidents and accidents suffered as the result of the heavy US military presence ${ }^{89}$, other kinds of burden bearing on Okinawa were widely ignored. ${ }^{90}$ This included large parts of the island's fragile environment being decimated and unprecedented levels of toxic pollutants, brought onto Okinawa during the Vietnam War, being stored there. These conditions were in concomitance with the consolidation of economic dominance by large (mostly mainland-based) business interests and the entrenchment of extra bureaucratic offices attached to key central government ministries, used to oversee local governance. These included Ministry of Foreign Affairs (MOFA) and Japan Defense Agency (JDA) (now Ministry of Defense (MOD)) branches specifically designated for dual oversight of Okinawan affairs. ${ }^{91}$ The contrast between mainland and Okinawan agency in portraying this reality is also striking. Okinawa's Prefectural Government, for example, regularly protested the multifaceted nature of Okinawa's burden under the guise of developmental policies. ${ }^{92}$ Contrastingly, the framing of Okinawa's burden by central authorities in Tokyo focused concertedly only on the US military presence itself. By so doing, the specifics of environmental destruction, economic cronyism and political controversy were widely ignored as a result.

\footnotetext{
${ }^{89}$ Hook, Mason and O'Shea, 'Regional Risk and Security'.

90 It should also be noted that Japan's national media outlets and mainstream newspapers have, despite points of critique, broadly articulated the narrative promulgated by the ruling administrations. Okinawa's two leading newspapers (Ryūkyū Shimpō and Okinawa Taimusu) have, in contrast, consistently both mocked these narratives and attempted to create a counter-narrative of pro-self-determination and resistance towards both the US and Japanese central government actors.

${ }^{91}$ Okinawa Sōgō Jimukyoku, 'Kaihatsu kensetsu bu'; Okinawa Defense Bureau, 'Yonagunijima e no rikujō jieitai'.

92 Ota; Johnson.
} 
Indeed, the US and Japanese central governments used the term burden in targeting what former Okinawan Governor, Inamine Keiichi, described as "points rather than lines",93, in order to tailor policy following flash-point incidents. This was in line with their temporally perceived security interests - rather than as a linear process adjusted in any meaningful way to meet the changing needs of most Okinawans. For instance, the headline case of a 12-year old girl raped by US marines in 1995 served as a catalyst to spark a review of Okinawa-policy that ultimately led to rationalizing US base facilities and inter-governmental legal provisions, but without any radical restructuring of existing governance structures. ${ }^{94}$ The US-Japan Special Action Committee (SACO) is a case in point. Openly created in response to Okinawan protests, most prominently targeting the 1995 rape case, in fact this agreement (overseen almost exclusively by central authorities in Washington and Tokyo) led to only very limited land returns on Okinawa and the downscaling of expendable military installations. These included a renewed commitment to relocate MCAS Futenma to a new replacement facility, which was subsequently approved on the coral reef at Henoko in fruition of a relocation project that was actually first conceived of in the 1960s. ${ }^{95}$ The tragic incident of a child being gang-raped was, thereby, used tactically at the state level to headline Okinawa's burden and the efforts Japanese central authorities were making to reduce it, whilst in-fact consolidating US troop deployments on the islands and further tightening cooperation in support of the US-Japan security alliance. ${ }^{96}$ Yet, while prefecture-wide opinion has remained against the relocation to Futenma, residents of the village of Henoko itself are overwhelmingly in favor of the base's construction as a means to boost the ailing local economy. ${ }^{97}$ This tension between competing local-level interests

\footnotetext{
93 Johnson, 6.

${ }_{94}$ Miyasato, Arasaki and Gabe (eds.), 'Okinawa 'jiritsu' e no michi'.

95 Rabson, 4. This also allowed for attention to be distracted away from the continuation of plans for controversial helipads to be built within natural forests inside the US military's Northern Training Area at Takae (see Voice of Takae).

96 MOFA, 'The Japan-U.S. Special Action Committee (SACO) Interim Report'.

97 Williams, 'The YIMBY Phenomenon in Henoko', 958.
} 
therefore further reflects the complex agency of Okinawans in engaging with the top-down governance structures by which they are constrained.

\section{Deterrence}

\section{Diet discourse}

In the post-9/11 era, a further shift in mainstream framings of Okinawa has witnessed a shift of focus towards the term deterrence. Initially as a function of the War on Terror, and later in reference to broader security concerns, Okinawa has been identified as a key strategic location for securing Japan's national defense within the context of current US-Japan security ties. Former Prime Minister, Koizumi Junichirō, for example, referred to military deterrence in relation to the US presence on the Islands an unprecedented thirty-eight separate times between 2004 and 2006 alone. ${ }^{98}$ Koizumi's successors - both within his own LDP party and the opposition Democratic Party of Japan (DPJ) - sustained this emphasis upon Okinawa's role in providing a supposed deterrence. Conjunctively, references to the reduction of Okinawa's burden were retained, but were consistently repositioned subordinately to the role of deterrence. For instance, Koizumi stated that:

In addition to ensuring that the effective deterrence held by stationed American military forces is maintained, I believe we must pay due consideration to the burden placed on local authorities where there are American military facilities present in their locality. It is from this perspective that we will pursue ongoing cooperative discussions with the American side. ${ }^{99}$

\footnotetext{
98 National Diet Library, 'Kantan kensaku'.

99 Upper House Main Session, 21 January 2004.
} 
This statement thereby illustrates the shift in emphasis upon the key terms used to portray Okinawa's role in relation to the on-going structural dominance of the US and its influence over the prefecture's governance.

Koizumi's articulation of this narrative of deterrence was, thereafter, reiterated and intensified by successive leaders, including Fukuda Yasuo and Asō Tarō, who asserted that "The Japanese and American sides share the understanding that, while maintaining our deterrence capabilities, it is possible to reduce the local burden borne by Okinawa." ${ }^{100}$ Notably, despite their rival political positions, leading opposition figures, including DPJ PMs Naoto Kan and Yoshihiko Noda, also essentially sustained this form of rhetoric. Following inaugural DPJ premier, Hatoyama Yukio's, failure to redirect either mainstream narratives or related policy on Okinawa ${ }^{101}$, Noda, for example, reconfirmed, in reference to deployment of the controversial US-made Osprey tilt-rotor military helicopter on the Islands, that:

Due to their deployment on Okinawa, the capabilities of the Marines have been improved, in addition to improving the deterrence capabilities of the US-Japan alliance in the Asia Pacific region, which we understand to be of paramount importance to our national security. ${ }^{102}$

Plagued by technical faults and combatable by hand-held pistol fire ${ }^{103}$, the Osprey deployment in fact offers little real deterrence. Yet, succeeding Noda, in return to LDP rule, PM Shinzō Abe also further decoupled the description of material capabilities on Okinawa from carefully worded rhetoric used to depict the Islands' role in national defense.

\footnotetext{
100 Main Session, 23 March 2007.

101 Hatoyama, 'Hatoyama naikaku sōridaijin kishakaiken'.

102 Main Session, 26 July 2012.

103 Peralta, 'Four US Service Members Injured in South Sudan', 1.
} 


\section{Discourse vs. policy and agency}

Watching elderly protesters forced to the ground and dragged away by government-funded security guards in front of Camp Schwab, Henoko, this decoupling is made all the more apparent. Here the gap between mainstream rhetoric and on-the-ground reality, accentuated in the post-9/11 era, perpetuates the pretext of deterrence. As with the use of terms such as development and burden, pivotal issues and incident points have been used to promote this concept. These include: responses to the 2004 US helicopter crash into Okinawa International University (OIU) $)^{104}$, the Chinese trawler-Japanese Coastguard collision incident off-shore of the disputed Senkaku/Diaoyu Islands in $2010^{105}$, and North Korean missile tests. ${ }^{106}$ These highlight at least two further functions of the narrative of deterrence which are often overlooked. The first relates to military accidents, such as the notorious crash of an American CH-53D Sea Stallion helicopter into OIU, adjacent to MCAS Futenma. ${ }^{107}$ This caused outrage throughout Japan, although more so among local authorities and media broadcasters ${ }^{108}$, but the means by which it was incorporated into the discourse of deterrence, making Okinawa a function of the wider construct of national security was illustrative of the processes discussed above. This revolved around using the accident as further evidence of the dangers of MCAS Futenma and justification, therefore, for relocation to Henoko in order to relieve Okinawa's burden. Contingently, the relocation was claimed to contribute towards the prefecture's military deterrence. Hence, due to Henoko base's construction - itself in violation of multiple Japanese laws ${ }^{109}$ - facing stiff prefecture-wide opposition, Japan's central government, in agreement with the US, seized the opportunity to both continue operations at MCAS Futenma and duly

\footnotetext{
104 Koizumi Junichiro, Main Session, 13 October 2004.

105 MOD, 'Senkakushotō to nichibei chii kyōtei ni kansuru shitsumon chūisho'.

${ }^{106}$ Asō Tarō, Special Committee on Okinawa and Northern Territories, 14 March 2007.

107 Hook, Mason and O'Shea, Regional Risk and Security in Japan, 168-9.

108 Okinawa Times; Ryukyu Shimpo, 14 August 2004.

${ }^{109}$ Sakurai, 'Japan's Illegal Environmental Impact Assessment of the Henoko Base', 2.
} 
blame their inability to end them upon those seeking to block its relocation to Henoko. Indeed, relocation to Henoko has repeatedly been stressed as "the only viable option"110 in order to maintain a sufficient deterrence. ${ }^{111}$ Similarly to the cases where development and burden were utilized as key terms of justification, rather than central authorities articulating how the overdeployment of bases and US service members is being imposed upon Okinawa regardless of local opinion and localized risks, the responsibility to host a deterrence (in the name of national security) has been reassigned to the Islands and their inhabitants. This is despite the fact that the majority of forces stationed on Okinawa do not, in military terms, provide an effective defensive deterrence. In particular, the Marines stationed at MCAS Futenma are an offensive force, which offer negligible ability to defend Okinawa (or Okinawans!) from external attack. $^{112}$

In addition, there is notable disparity between the use of political rhetoric, actual policy and the contradictory interests of Okinawans with regards to JSDF forces and facilities increasingly being deployed to fortify Okinawa. This initiative compliments the misrepresentation of the US military deterrence, but also masks a Japanese military build-up that has raised minimal domestic opposition. Indicative of this trend, are the cases of new JSDF facilities on outlying Ishigaki Island, Miyako Island and Yonaguni Island. ${ }^{113}$ On Yonaguni in particular, local inhabitants of Japan's sparsely populated western frontier have been swayed to accept the militarization of their natural environment and dilution of local government powers via economic incentives offered in return. These are comparable to those offered to local villagers at Henoko, and have once again been framed in terms of the necessity for increased

\footnotetext{
${ }^{110}$ Suga Yoshihide, Cabinet Committee, 9 March 2016.

${ }^{111}$ A comparable discourse is also applied to the case of helipads constructed at Takae, noted above.

112 Mochizuki, 'Yokushiryoku to zaioki beiheitai'; Yara, 'Kaiheitai okinawa chūryū'.

113 Ikeo, Okada and Mason.
} 
deterrence. ${ }^{114}$ Yet, the JSDF presence in itself presents unclear benefits by way of deterring any would-be regional threat - particularly as it may itself become a target of rival militaries. ${ }^{115}$ This illustrates, then, how the narrative of deterrence in relation to Okinawa facilitates the diversification of national security policy initiatives and seeks to either coopt or diffuse local agency.

It also highlights how Okinawa's fragmented population has been misrepresented by much of the mainstream media and literature alike, but is the victim of monolithic counter-narratives created by local political actors and news media sources that oppose central government and US authorities. In this regard, the politically incorrect notion that "anyone in Okinawa can be bought"116, which is not incompatible with the discourse articulated via the key terms discussed above, suggests that while staunch resistance to American bases is certainly obfuscated by the central government's fallacious narrative of deterrence, so too is the real nature of competing Okinawan interests. Indeed, overwhelming local support from within the village of Henoko (on economic grounds) for the relocation of the MCAS Futenma base to the offshore coral reef site there was forthcoming. And, in addition, Yonaguni and other outlying Islands' have endorsed the new JSDF bases, as well as the recent concreting over of green-space reclaimed from US forces in Kitanakagusuku to create a lucrative giant mall complex, reinforcing the multifaceted distortions of these on-the-ground realities. ${ }^{117118}$

\footnotetext{
114 Okinawa Times, 30 March 2016

115 Okinawa Defense Bureau, 6.

${ }^{116}$ Campbell, 'Nationalism in Okinawa'.

117 Williams, 959.

${ }^{118}$ Ryūkyū Shimpo 26 April 2015, 1.
} 


\section{Conclusion}

Ultimately, it is problematic to disentangle each of the key terms discussed above from what could be defined as an objective narrative. Nonetheless, each exist in juxtaposition to objectively distinguishable realities on Okinawa that contain a more diverse range of local voices and agency than can be expressed through the monolithic framings of development, burden and deterrence. ${ }^{119}$ In that sense, this article has illustrated how contemporary Okinawa has been characterized by false narratives, or narrative fallacies ${ }^{120}$, since its reversion to Japanese rule. The discussion thereby highlighted how these narrative constructs have facilitated the decoupling of Okinawa-policy from the mainstream political rhetoric that frames it, but also how this process often leads to the further misrepresentation of Okinawan agency as being predominantly uniform - rather than exposing its diverse composition. Deconstruction of these terms and their contested usage made clear the endurance of a system of governance on Okinawa that perpetuates the Prefecture's political and economic division and rule, largely in disregard or cooption of the agency of its locally elected representatives and citizens, and in continued destruction of its marine environment.

In this regard, the present article has built on both mainstream and critical literatures in offering a more nuanced account of Okinawa's structure-agency composition than leading disciplinary paradigms have, as yet, been able to persuasively provide. This rests upon the understanding that, particularly in the post-reversion era, the reality of Okinawa's governance revolves around its misrepresentation by leading politicians, media actors and others in positions of relative power, as well as politically active stakeholders on Okinawa itself. The essence of this process of false narration, then, is that by framing Okinawa as a unique other, particularly in terms of

119 Howarth, Discourse, 48-66.

120 Taleb, The Black Swan, 62-63. 
its roles within the national political body of Japan, the actual trajectory and prioritization of government policies being implemented become obfuscated via the opaque rhetorical terms that broadly cover the concept of security. This has led to the relative neglect of important issues such as long-term socioeconomic disparity, environmental degradation and regional geo-strategy. These are also exacerbated by stereotypical framings of the Islands, a protracted US military presence and shortsighted policymaking.

As highlighted in the analyses of contradictions between Diet statements made by successive premiers and the policies that they have overseen, this neglect has affected multiple areas of significance on Okinawa. These include: indifference towards forms of sexual exploitation in the name of development; massive degradation and pollution of marine ecosystems under the pretext of necessary burden, and a sustained offensively-oriented US (and increasingly Japanese) military presence framed as deterrence. ${ }^{121}$ From a normative perspective, which designates Okinawan agency as its first priority and seeks to engage more fully with Okinawan narratives, the central question is surely, then, how to create and disseminate more critical interpretations of Okinawan interests. These need to both expose existing false narratives and replace them with a depiction of Japan's southernmost prefecture that redresses its enduring structural weaknesses. This is a project that requires a comprehensive process of reconciliation between Okinawa's colonial past and present, and is likely to be realized only through constructive policy measures that ensure a less economically dependent and more politically independent future. Therein, the necessity for more consistent coupling of political narratives with the policies they frame is made abundantly clear.

121 Pilger. 


\section{$\underline{\text { References }}$}

Abe, Shinzo, Atarashii kuni e utsukushii kuni e, kanzenban [Toward a Beautiful Country]. Tokyo: Bungeishunju, 2013.

Akadome, Yasunori. 2013. 'Henoko shinkichi’ ga hoshii no wa beikoku de wa naku bōeishō Da' [It's the Ministry of Defense not America who Want the New Henoko Base]. Magajin, 2013, http://www.magazine9.jp/okadome/110629/ (accessed 22 April 2017).

Arakawa, Akira. and Oguma E, ‘Oguma kenkyū 1: saishū repōto’ [Oguma Research 1: Final Report]. Keio University, 2003.

Anderson, Benedict, Imagined Communities. London: Verso, 1983.

Arasaki, Moriteru, ed., Kankō kōsu de nai Okinawa: senseki, kichi, sangyō, shizen, Sakishima [Okinawa off the Tourist Route: War scars, bases, coral and the Sakishimas]. Tokyo: Kokubunken, 2008.

Arazato, Kinpuku and Oshiro T, Kindai Okinawa no ayumi (1972 nen): Okinawa no hyakunen (1) [The History of Modern Okinawa (since 1972): 100 Years of Okinawa]. Tokyo: Taihei shuppansha, 1969.

Asahi Shimbun, 'Ota motochiji “makete mo teikō suru shika nai” henoko haiso' [The loss of Henoko: Former Governor Ota says 'resistance is all that can be done even in the face of defeat'], 2016, http://www.asahi.com/articles/ASJDN4WDRJDNTIPE016.html (accessed 31 March 2017).

Blaxell, Vivian, 'Preparing Okinawa for Reversion to Japan: The Okinawa International Ocean Exposition of 1975, the US Military and the Construction State', Japan Focus, 8:29(2) (2010): 1-20.

Campbell, John, Discussant comments for 'Nationalism in Okinawa: Case study of 
Futenma Base', DIJ Tokyo Social Science Study Group, German Institute of Japanese Studies (DIJ), November, 2014.

Chanlett-Avery, Emma and Rinehart, Ian, 'The U.S. Military Presence in Okinawa and the Futenma Base Controversy', Congressional Research Service Report, 7-5700, 2016.

Chomsky, Noam and Herman, Edward S., Manufacturing Consent: The Political Economy of the Mass Media. New York: Vintage, 1995.

Dietz, Kelly, 'Transnationalism and Transition in the Ryūkyūs', in Iacobelli, Pedro, Danton Leary and Shinnosuke Takahashi, Transnational Japan as History: Empire, migration and social movements. New York: Srpinger, 2016, 211-241.

Dreher, Rod, 'The Narrative Fallacy' The American Conservative, 2012, http://www.theamericanconservative.com/dreher/the-narrative-fallacy/ (accessed 8 February 2017).

Figal, Gerald, Beachheads: War, peace and tourism in postwar Okinawa. Lanham: Rowman and Littlefield, 2012.

Gabe, Masāki, (Comments) in McCormack, Gavan and Norimatsu S.O. Resistant Islands: Okinawa Confronts Japan and the United States. Lanham: Rowman and Littlefield, 2012, ix.

Glosserman, Brad and Kang, David C., The Myth of Japanese Remilitarization. The National Interest, 15 October, 2014, http://nationalinterest.org/feature/the-myth-japaneseremilitarization-11470 (accessed 13 June 2017).

Hatoyama, Yukio, 'Hatoyama naikaku sōridaijin kishakaiken' [Press conference of Prime Minister Hatoyama]. 28 May, 2010.

Hatoyama, Yukio, ed., Higashiajia kyōdōtai to Okinawa no mirai [A Unified East Asia and Okinawa's Future]. Tokyo: Kadensha, 2014.

Hook, Glenn, Mason, Ra and O'Shea, Paul, Regional Risk and Security: Whither the 
everyday. Abingdon: Routledge, 2015.

Hook, Glenn and Siddle, Richard, Japan and Okinawa: Structure and subjectivity. Abingdon: Routledge, 2003.

Hoshino, Eichi, 'Okinawa no beigun kichi mondai to ningen no anzenhoshō' [Okinawa's US Military Base Issues and Human Security]. Seisaku kagaku: kokusai kankei ronshū, 15, betsusatsu [excerpts], 2013.

Hosoya, Yuichi, ‘The Role of Japan's National Security Council', AJISS-Commentary. 199:17 (2013): 1-4.

Howarth, David, Discourse. Buckingham: Open University Press, 2000.

Hughes, Christopher, Japan's Remilitarization. London: Routledge, 2009.

Hunt, Richard, 'Melvin Laird and the Foundation of the Post-Vietnam Military: 1969-

1973 'Washington DC: Historical Office of the Secretary of Defense, 2015.

Ikeo, Yasushi, Okada, Satoshi and Mason, Ra, 'Watashi ni yokute anata ni ii Yonaguni wa watashitachi no mirai sono mono' [The Yonaguni that is Good for Me and for You: The Future Itself]. Panel Disscussion. 30 May, Yonaguni Multifunction Facility, 2015. Inoue, Masamichi, Okinawa and the US Military: Identity making the age of globalization. Columbia: Columbia University Press, 2017.

Japan Association of Bar Associates (JFBA), 'Okinawa fukki nishūnen ni atatte' [At the $\begin{array}{llll}\text { Second } & \text { Anniversary }\end{array}$ http://www.nichibenren.or.jp/activity/document/statement/year/1974/1974_2.html (accessed 22 March 2017).

Jimbo, Tetsuo, Shinji Miyadai, Yoshikazu Makishi, Yōhei Iha, Masahide Ota and Masaaki Gabe, Okinawa no shinjitsu, yamato no giman: beigun kichi to nihon gaikō no kubiki [The Truth about Okinawa and the Mainland's Arrogance: US Military Bases and the Noose of Japanese Diplomacy]. Tokyo: Shunjusha, 2010. 
Johnson, Chalmers, 'Three Rapes: The Status of Forces Agreement and Okinawa' Japan Policy Research Institute (JPRI). Working paper No.97, January (2003).

Kurōzuappu gendai, 'Henoko isetsu' tairitsu no shinsō' [The True Face of Conflict over the 'Henoko Relocation']. NHK Television broadcast, 19 November, 2015.

Lim, Chuam-tiong, Identity Politics in 'Peripheral East Asia': Okinawa, Taiwan and Hong Kong. Tokyo: Akashi shoten, 2005.

Martinez Lirola, Maria, 'Multimodal analysis of a sample of political posters in Ireland During and After the Celtic Tiger' Revista Signos, 49:91 (2016): 245-264.

Mason, Ra, 'Japan's change in military outlook marks the end of a 'Peace State', The Conversation, 2016, Accessed January 4, 2017: https://theconversation.com/japanschange-in-military- outlook-marks-the-end-of-a-peace-state-68864 (accessed 4 January 2017).

Mason, Ra, 'Nationalism in Okinawa: Futenma and the Future of Base Politics' International Review of Ryukyuan and Okinawan Studies, 5 (2016b): 15-44.

Matsui, Kazuhiko, 'Okinawa shinkō no kadai to kongo no shinkōsaku no arikata' [Issues of Okinawa's Development and Development Policies Going Forward]. Upper House Legislation and Survey Report, 324 (2012): 137-148.

Matsushima, Yasukatsu, Ryukyu dokuritsuron: Ryukyu minzoku no manifesuto [Theories of Ryukyu Independence: Ryukyuan People’s Manifesto]. Tokyo: Basilico, 2014. Matsumura, Wendy, The Limits of Okinawa: Japanese capitalism, living labor, and theorizations of community. Durham: Duke University Press, 2015.

McCormack, Gavan. and Satoko Oka Norimatsu, Okinawa no ikari: nichibei e no teikō [Resistant Islands: Okinawa Confronts Japan and the United States]. Kyoto: Horitsu Bunkasha, 2012.

Meisels, Tamar, Territorial Rights ( $2^{\text {nd }}$ Edition). New York: Springer, 2009. 
Mitchel, Jon, 'Vietnam: Okinawa's 'forgotten war', Japan Focus, 13:16(1) (2015): 1-7.

Miyazato, Seigen, Moriteru Arasaki and Masaaki Gabe, Okinawa 'jiritsu' e no michi wo motomete: kichi, keizai, jichi no shiten kara [Seeking a path to Okinawan 'independence': From the perspectives of bases, economy and local authority]. Tokyo: Kōbunken, 2009.

Mochizuki, Mike, 'Yokushiryoku to zaioki beiheitai' [Deterrence and US Forces on Okinawa]. In Shingaikō inishiativu, ed., Kyozō no yokushiryoku: Okinawa, tōkyō, washinton hatsu anzenhoshō seisaku no shinkijiku. Tokyo: Junposha, 2014, 97-128.

MOD, 'Zaioki beikaiheitai no 'yokushiryoku' ni kansuru shitsumon ni taisuru tōbensho' [Written Responses to Questions Concerning US Forces on Okinawa], 2010 http://www.mod.go.jp/j/presiding/touben/174kai/syu/tou518.html (accessed 31 March 2017).

MOD, ‘Senkakushotō to nichibei chii kyōtei ni kansuru shitsumon chūisho’ [Notes on Questions Regarding the The Senkaku Islands and US-Japan Status of Forces Agreement], 2010, http://www.mod.go.jp/j/presiding/touben/176kai/syu/situ44.html (accessed 1 April 2017).

MOFA, 'The Japan-U.S. Special Action Committee (SACO) Interim Report', 1996, http://www.mofa.go.jp/region/n-america/us/security/seco.html (accessed 27 March 2017).

Moore, Margaret, ed., National Self-Determination and Secession. Oxford: Oxford University Press, 1998.

Moriya, Takemasa, “'Futenma” kōshō no hiroku' [Secret Memoirs of 'Futenma's Negotiation]. Tokyo: Shinchosha, 2010.

Naha City Museum of History, 'Okinawa kokusai kaiyō hakurankai kanren shiryō' 
[Documents on the Okinawa International Ocean Expo.]. Expo 75, 2017, http://www.rekishi-archive.city.naha.okinawa.jp/archives/item5/63507 (accessed 27 March 2017).

Nakasone, Yasuhiro, Press Statement, Head of State Summit Meeting. Washington, 27 May, 1983.

Norris, Sigrid, 'What is a mode? Smell, Olfactory Perception, and the Notion of Mode in Multimodal Mediated theory', Multimodal Communication, 2:2: (2013): 155-169.

Namihira, Tsuneo, Kindai higashiajiashi no naka no ryūkyū heigō: chūka sekai chitsujo kara shokuminchi teikoku nihon e [Ryukyu Annexation amid Modern East Asia: From the Chinese World Order to the Japanese Colonial Empire]. Tokyo: Iwanami Shoten, 2014.

Nankuru gumi, Okinawa ga dokuritsu suru hi [The day Okinawa gains independence]. Tokyo: Natsume shobō, 2006.

National Diet Library, Kantan kensaku [Simple search] (various search terms), 2017, http://kokkai.ndl.go.jp/ (accessed 31 January 2017 - 31 July 2017).

National Security Archive, 'Nuclear Weapons on Okinawa Declassified December 2015, Photos Available Since 1990', 2016, http://nsarchive.gwu.edu/nukevault/ebb541Nukes-on-Okinawa-Declassified-2016/ (24 February 2017).

Newsham, Grant, 'US military bases on Okinawa: still an essential deterrence', Asia Times, 2015, http://www.atimes.com/article/us-military-bases-on-okinawa-still-anessential-deterrence// (accessed 31 March 2017).

Norimatsu, Satoko, 'Hatoyama Trumps Mubarak'. Japan Focus, 9:9(3) (2011): 1-18.

Okinawa Defense Bureau, 'Kensetsu kōji kankei’ [Concerning Construction Projects], 2017, http://www.mod.go.jp/rdb/okinawa/01nyusatsu/kensetsu/index.html (accessed 11 April 2017) 
Okinawa Defense Bureau, 'Yonagunijima e no rikujō jieitai no engan kanshi butai haichi nado ni kakawaru chintaishaku keiyaku ni tsuite' [Concerning the Lease Contract with Regards the Deployment and Related Matters of a Coastal Observation Unit of the Land Self Defense Force to Yonaguni Island]. Okinawa bōeikyoku kōhō, 146 (2013): 6.

Okinawa Prefectural Peace Memorial Museum, 'Battle of Okinawa' (permanent exhibition), 2018.

Okinawa Sōgō Jimukyoku, 'Kaihatsu kensetsu bu’ [Development Construction Division], 2017, http://www.ogb.go.jp/ (accessed 10 April 2017).

Ōkubo, Jun, Gensō no shima Okinawa [Island of Illusion: Okinawa]. Tokyo: Nikkei Inc, 2009. OPN LA, 'Current Issues in Post-Reversion Okinawa', 2005, http://www.uchinanchu.com/uchinanchu/history_current.htm (accessed 22 March 2017).

Oshiro, Tsuneo, K. Takara and M. Maeshiro, Okinawa inishiachivu: Okinawa hatsu chiteki senryaku [Okinawa Initiative: Normative strategies from an Okinawan perspective]. Naha: Hirugisha, 2000.

Ota, Masahide, Essays on Okinawa Problems. Uruma: Yui Shuppan, 2000.

Ota, Masahide, 'Okinawa kokusai heiwakenkyūjo' [Okinawa International Peace Research Institute], 2013, http://www.opri.jp/index.html (accessed 2 April 2017).

Ozawa, Ichirō, Blueprint for a New Japan. Tokyo: Kodansha International, 1994.

Paltridge, Brian, Discourse Analysis: An introduction. New York: Bloomsbury, 2012.

Peralta, Eyder, 'Four US Service Members Injured in South Sudan’, NPR, 2013, https://www.npr.org/sections/thetwo-way/2013/12/21/256007086/four-u-s-servicemembers-injured-in-south-sudan (accessed 17 April 2018).

Pilger, John, 'The Coming War with China: a film by John Pilger', ITV, Dartmouth Films, 2017. 
Rabson, Steve, 'Henoko and the U.S. Military: A History of Dependence and Resistance' The Asia-Pacific Journal: Japan Focus, 10:4(2) (2012): 1-16.

Ryukyu Shimpo, 'Ion mōru okinawa raikamu kaigyō: hakyūkōka ni kitai’ [AEON Mall Okinawa Rycom opens: Expectations for a knock-on effect] 26 April 2015, 1. Sakaiya, Taichi, 'Okinawa kaiyōhakurankai wa seikō datta ka' [Was the Okinawa International Ocean Expo a Success?], 2015, https://dot.asahi.com/column/sengo70/2015110200057.html (accessed 25 March 2018). Sakurai Kunitoshi, ‘Japan's Illegal Environmental Impact Assessment of the Henoko Base', Japan Focus. 10:9(5) (2015): 1-6.

Sakurazawa, Makoto, 'Okinawa dokuritsu ron no kentō: Ōgimi Chōtoku wo chūshin ni' [Considering Okinawan Independence: The Central Role of Ōgimi Chōtoku], in Izuhara, M., ed., Sengo nihon shisō to chishikijin no yakuwari. Kyoto: Horitsu Bunka Sha, 2015, 372-96.

Sato, M., 'Amerika seiji to zaioki beigun kichi' [American Politics and US Military Bases on Okinawa] in Shimabukuro, Jun and K. Abe, Okinawa ga tō nihon no anzen hoshō. Tokyo: Iwanami Shoten, 2015, 227-56.

Shimabukuro, Jun, ““Okinawa aidentiti” to Okinawa jūmin no jiko ketteiken' [Okinawan Identity and Okinawan Citizens' Right to Self-Determination], 2015, http://www.nippon.com/ja/in-depth/a04501/ (accessed 10 April 2018).

Son, Key-young and Ra Mason, 'Building a maritime 'great wall' to contain China? Explaining Japan's recalibration of risk with the militarization of Okinawa' Asian Perspective, 37 (2013): 437-461.

Sonoda, Kōji 'Beigun izon: yokushiryoku ni hisomu risuku' [Reliance upon the US military: Hidden risks of deterrence]. Asahi Shimbun (editorial), 22 December 2017, 12. 
Statistics Bureau, Ministry of Internal Affairs and Communications (MIC), 'Labour

Force Survery: Quarterly and annual average figures - Results by region', 2017, http://www.stat.go.jp/english/data/roudou/lngindex.htm (accessed 3 April 2018).

Suda, Shintarō, K. Yabe and H. Maedomari, Hondo no ningen wa shiranai ga, Okinawa no hito wa minna shitte iru koto: Okinawa beigun kichi kankō gaido [Things that Mainlanders don't Know but Every Okinawan Knows: A Tourist Guide to American Military Bases on Okinawa]. Tokyo: Shoseki-Johosha, 2011.

Takahashi, Junko, Okinawa 'fukki' no kōzō: nashonaru aidentiti no hensei katei [The Structure of Okinawan Reversion: The Process of Revising National Identity]. Tokyo: Shinjuku shobō, 2011.

Takara, Ben, Okinawa seikatsushi [Life on Okinawa], Tokyo: Iwanami Shoten, 2005.

Takara, Miki, I. Yokuda and N. Kuramoto, 'Can we measure 'Okinawan Identity'?:

Survey for undergraduate Students in Okinawa' Journal of Quality Education, 4 (2010): 132-148.

Taleb, Nassim, The Black Swan, London: Penguin, 2008.

Tanji, Miyumi, Myth Protest and Struggle in Okinawa, Abingdon: Routledge, 2006.

The Asahi Shimbun Company, Media, Propaganda and Politics in $20^{\text {th }}$-Century Japan. Barrack Kushner trans. Tokyo: The Asahi Shimbun Company, 2015.

Wæver, Ole, 'Securitization and Desecuritization', in Ronnie D. Lipschutz (ed). On Security. New York: Columbia University Press, 1995, 46-86.

Washington Post, 'The Long Shadow of the "National Nightmare"', 2012, https://www.washingtonpost.com/politics/watergate/ (accessed 24 February 2018).

Williams, Brendan, 'The YIMBY Phenomenon in Henoko, Okinawa Compensation Politics and Grassroots Democracy in a Base Community’ Asian Survey, $53: 5$ (2013): 958-978. 
Wodak, Ruth, 'Critical discourse analysis', in Seale, Clive et al. (Ed.), Qualitative Research Practice: Concise Paperback Edition, London: Sage, 2004, 185-202.

Wood, Linda and Rolf Kroger, Doing Discourse Analysis: Methods for studying action in talk and text, Thousand Oaks: Sage, 2000.

Voice of Takae 'No War! Yes Peace!', 2012, http://nohelipadtakae.org/files/VOT-jp2015June28.pdf (accessed 20 May 2018).

Yamaguchi, Eitetsu. and Y. Arakawa, The Demise of the Ryukyu Kingdom: Western accounts and controversy. Ginowan: Yojushorin, 2002.

Yamazato, Chōsei, 'Zaijūgaikokujin to no kondankai' [Public Discussion with Resident Foreigners], Public debate, Itoman City Office Mayors Office. 10 July, 2005.

Yara, Tomohiro, 'Kaiheitai Okinawa chūryū to anzenhoshō shinwa' [The Deployment of Marines on Okinawa and the Myth of Security], in Shingaikō inishiativu, Kyozō no yokushiryoku: Okinawa, tōkyō, washinton hatsu anzenhoshō seisaku no shinkijiku. Junposha: Tokyo, 2014, 33-78.

Yoron What Japan Thinks, 'Okinawa identity’ (opinion poll), 2010, http://whatjapanthinks.com/2010/05/04/okinawa-identity/ (accessed 7 April 2017).

Yoshida, Kensei, 'US Bases, Japan and the Reality of Okinawa as a Military Colony', Japan Focus, 6:8(0) (2008): 1-11. 